\title{
The role of hepatic progenitor cells in predicting response to therapy in Egyptian patients with chronic hepatitis C, genotype 4
}

\author{
Thanaa El A Helal ${ }^{1}$, Nehal A Radwan ${ }^{1}$, Heba A Mahmoud ${ }^{1}$, Ahmed ME Zaki ${ }^{1}$, \\ Naglaa S Ahmed ${ }^{1}$, Ali AA Wahib², Ahmed M Aref ${ }^{3}$
}

1. Department of Pathology, Faculty of Medicine, Ain Shams University, Ramses Street- New Faculty Bldg. $-5^{\text {th }}$ floor, P.O. \# 11566 Cairo, Egypt.

2. Department of Internal Medicine, Faculty of Medicine, Al-Azhar University, Cairo, Egypt.

3. Faculty of Biotechnology, October University for Modern Sciences and Arts (MSA) Giza, Egypt.

\section{Emails:}

Thanaa El A Helal: Thanaahelal2@hotmail.com, Nehal A Radwan: neharadwan@yahoo.com, Heba A Mahmoud: heba. ahmed60@gmail.com, Ahmed ME Zaki: mohyzb@hotmail.com, Naglaa S Ahmed: naglaasamier@yahoo.com, Ali AA Wahib: aliwahib@hotmail.com, Ahmed M: Aref: a_aref23@hotmail.com

\begin{abstract}
Background: Interferon therapy is used as a line of treatment of chronic hepatitis $\mathrm{C}$ virus $(\mathrm{HCV})$ in several areas of the world including Egypt.

Objective: Our aim was to investigate the value of hepatic progenitor cells (HPCs) in predicting response of patients with chronic HCV, genotype 4 to pegylated interferon (PEGIFN) plus ribavirin (RBV) therapy.

Methods: Pre-treatment liver biopsies obtained from 110 patients with chronic HCV, genotype 4 were examined immunohistochemically for HPCs using cytokeratin19. The mean number of HPCs as ductular reaction (DR) and as isolated progenitor cells (IPCs) was counted in each case. The patients were classified into: those with sustained virological response (SVR) and those who did not achieve SVR. The results were compared between the two groups. Also, the relationships between HPCs and other clinico-pathologic variables were estimated using multivariate analysis.

Results: The mean number of HPCs was the only independent predictor of therapeutic response, being significantly higher in non-responders $(\mathrm{P}=0$ for $\mathrm{DR}$ and $\mathrm{P}=0.03$ for IPCs). On the other hand, fibrosis stage and steatosis were the only independent factors which showed a significant direct association with the mean number of HPCs in the form of DR and IPCs (P $=0$ for each).

Conclusion: The number of HPCs provides prognostic information in chronic HCV since it is significantly associated with stage of fibrosis. More importantly, it can be used as a marker to predict response of patients with chronic HCV to PEGIFN plus RBV therapy.
\end{abstract}

Keywords: Chronic hepatitis C, genotype 4, response to therapy, hepatic progenitor cells.

DOI: https://dx.doi.org/10.4314/ahs.v19i1.14

Cite as: Helal T El A, Radwan NA, Mabmoud HA, Zaki AME, Abmed NS, Wabib AAA, et al. The role of hepatic progenitor cells in predicting response to therapy in Egyptian patients with chronic hepatitis C, genotype 4. Afri Health Sci. 2019;19(1). 1411-1421. bttps://dx.doi. org/10.4314/abs.v19i1.14
Corresponding author:
Nehal A Radwan,
Pathology department,
Faculty of Medicine,
Ain Shams University,Cairo, Egypt.
Ramses Street- New Faculty Bldg.
-5th floor- office 1/1, P.O. \# 11566-Cairo, Egypt.
Telephone:(+202) 01223832549
Email: neharadwan@yahoo.com

\section{Introduction}

Hepatitis $\mathrm{C}$ virus (HCV) infection is one of the most common health problems in Egypt with about 10\% of the population infected ${ }^{1,2}$. The wide implementation of the recently introduced direct acting anti-virals is hampered by their high cost and the possible resistance on long terms ${ }^{3}$. Therefore, the combined treatment with interferon (IFN) and ribavirin (RBV) is still used as line of treatment of $\mathrm{HCV}$-infected patients ${ }^{4-6}$. Nevertheless, this therapy has a high rate of non-response and is associated

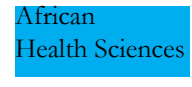

(C) 2019 Helal et al. Licensee African Health Sciences. This is an Open Access article distributed under the terms of the Creative commons Attribution License (https://creativecommons.org/licenses/BY/4.0), which permits unrestricted use, distribution, and reproduction in any medium, provided the original work is properly cited. 
with side effects ${ }^{7}$. Several host and viral factors have been investigated to be used as markers to predict the response of chronic hepatitis $C$ patients to the combined IFN and RBV treatment. Viral load was evaluated as a predictive factor by some studies with controversial results ${ }^{8-10}$. The stage of liver fibrosis was claimed to be a good predictor of treatment response in HCV infection ${ }^{9,11}$. However, this claim could not be supported by others ${ }^{8,10,12}$ Last but not least, was the genotyping of IL-28 B which has been reported to be a strong predictor of treatment outcome in HCV patients ${ }^{10,13-15}$. However, estimation of this parameter needs sophisticated molecular techniques which are not usually available in general hospitals.

Hepatic progenitor cells (HPCs) are small cells located in the periportal region of the liver ${ }^{16}$. Although the role of HPCs in liver fibrogenesis has been extensively studied $^{9,10,17,18}$, their value in predicting sustained virological response of patients with HCV to treatment was not previously evaluated except in two reports. The first was Tsamandas et al. ${ }^{17}$ on 77 patients with HCV of different genotypes. The second was performed on pediatric cases ${ }^{12}$.

In the current study, we aimed to investigate the importance of HPCs in predicting sustained virological response in adult patient with chronic HCV genotype 4.

\section{Material and methods pecimen collection}

This is a retrospective study which comprised randomly selected 110 needle liver biopsies from patients with chronic HCV admitted for anti-viral therapy during the period from January 2010 to December 2013. The inclusion criteria included: 1) Patients older than 18 years and equal or less than 65 years. 2) HCV genotype 4. 3) Pretreatment liver biopsies. 4) Liver biopsies containing at least 5 portal tracts. The exclusion criteria were: 1) Coinfection with hepatitis B virus. 2) Presence of other liver diseases. 3) Patients discontinued treatment. The study protocol was approved by the Research Ethical Committee, Faculty of Medicine, Ain Shams University.

\section{Demographic and laboratory data}

The patients' records were reviewed to retrieve the patient's age, gender and pre-treatment serum level of HCV-RNA (estimated by quantitative polymerase chain reaction). The patients were classified into two groups: low viremia $(<600.000 \mathrm{IU} / \mathrm{ML})$ and high viremia $(\geq$ $600.000 \mathrm{IU} / \mathrm{ML}) 9$.

\section{Therapeutic protocol}

All 110 patients were treated with pegylated interferon (PEG IFN) alpha 2a and ribavirin (RBV) for a period of 48 weeks, following the protocol recommended by Derbala et al. $(2005)^{19}$. The criteria for anti-viral therapy included age $\leq 65$ years, elevated liver enzymes at least 1.5 times the upper limit of normal for 24 weeks and liver pathology with METAVIR stage of fibrosis $\geq 1^{20}$. Serum HCV-RNA was estimated while on treatment at weeks 12, 24, 48 and at 24 weeks after completing therapy. Patients were categorized according to Rizk et al. ${ }^{10}$ into two groups: responders including patients with sustained virological response (SVR) who had undetectable serum HCV-RNA by PCR assay 24 weeks following stopping therapy after achieving end of treatment. The second group (non-responders) consisted of patients who had relapse (reappearance of the serum HCV-RNA after end of treatment), patients with viral breakthrough (reappearance of serum HCV-RNA while still on therapy after initial disappearance) and patients who never achieved undetectable serum HCV-RNA.

\section{Histopathologic study}

Hematoxylin and Eosin-stained and Masson Trichrome-stained tissue sections were examined for grading of the necroinflammatory activity (A) and staging of fibrosis (F) according to METAVIR scoring system 21. For statistical analysis; necroinflammatory activity was classified into $\mathrm{A} 1$ and $\mathrm{A} 2+\mathrm{A} 3$, also stage of fibrosis was grouped as: F1 + F2 and F3 + F4. No A 0 or F 0 cases were included in the study. Steatosis was considered as absent or present when more than $5 \%$ of the hepatocytes affected $^{22}$.

\section{Immunohistochemistry}

Four micron-thick tissue sections were cut from the paraffin blocks for all the 110 liver biopsies onto positively charged slides. These sections were immunostained for cytokeratin 19 (CK19) using ready to use CK19 monoclonal mouse antibody (Cat. No 319-M18, cell Marque, Rocklin, USA). CK19 was considered as the most sensitive marker for immunohistochemical demonstration of $\mathrm{HPCs}^{17,23}$. The immunostaining study was performed by applying avidin-biotin detection kit (Zymed, San Francis- 
co , USA) and following the technique of Hsu et al. ${ }^{24}$, using an automated machine (Ventana Medical Systems, Inc. Tucson, Arizona, USA), according to the manufacturer protocol. Bile ducts in the liver biopsies were used as a positive built- in control. Negative control was performed by following the same steps except for adding BSA in PBS instead of the primary antibody. For control purposes, 10 needle liver biopsies obtained from liver donors with normal histology were immunostained for CK19.

\section{Interpretation and quantification of immunostain- ing}

Brownish cystoplasmic staining was considered positive. According to Roskams et al. ${ }^{25}$, positively stained HPCs were searched for in the periportal area where they form ductular reaction (DR) and in the liver parenchyma where they are scattered as isolated progenitor cells (IPCs). For each liver biopsy, the whole tissue section was examined under higher power magnification $\times 400$ to count manually the number of DR and IPCs separately. Then, the mean number of each cell type per one high power field (HPF) was taken ${ }^{17}$.

\section{Statistical analysis}

IBM SPSS statistics (V. 23.0, IBM Corp., USA, 2015) was applied for data analysis. Quantitative data were expressed as range and means $\pm \mathrm{SD}$. Categorical variables were given as numbers and percentages. Relationships between HPC expression and clinicopathologic variables and comparison between responders and non-responders regarding these variables were performed by using one-paired student $\mathrm{t}$ test for numerical variables and Chi square test for categorical variables. Multivariate analysis was then done to identify independent determinants. Correlation between the values of DR and IPCs was estimated by applying Spearman's rank correlation coefficient test. For all tests, $P$ value less than 0.05 was considered statistically positive.

\section{Results}

\section{Patients' data and treatment response}

The 110 liver biopsies were obtained from 96 males $(87.3 \%)$ and 14 females $(12.7 \%)$. The ages of patients ranged between 21 and 62 years (mean $44.0 \pm 8.03$ ). Seventy two had low viremia $(65.5 \%)$ and 38 had high viremia $(34.5 \%)$. SVR was achieved in 47 out of the $110 \mathrm{pa}-$ tients (responders) (42.7\%). The non-responders were 63 patients(57.3\%). They consisted of 11 relapsers, 25 with viral breakthrough and 27 not achieved response.

\section{Histologic data}

The necroinflammatory disease activity (A) was found to be A1 in $61(55.5 \%), \mathrm{A} 2$ in $32(29 \%)$ and $\mathrm{A} 3$ in 17 cases $(15.5 \%)$. Fibrosis stage (F) was: F1 (38, 34.5\%), F2 (28, $25.5 \%), \mathrm{F} 3(34,30.9 \%)$ and F4 (10, 9.1\%). Steatosis was absent in $62(56.4 \%)$ and present in 48 cases $(43.6 \%)$.

\section{HPC expression}

Six of the 10 normal liver biopsies showed scanty HPCs in the form of IPCs (Figure 1). On the other hand; all 110 liver biopsies with chronic HCV showed HPCs as DR and IPCs (Figure $2 \& 3$ ). The number of DR ranged between 1 and 17.9 with a mean $4.7 \pm$ 3.0. The number of IPCs ranged between 0.6 and 10.3 with a mean $3.7 \pm$ 2.1. 


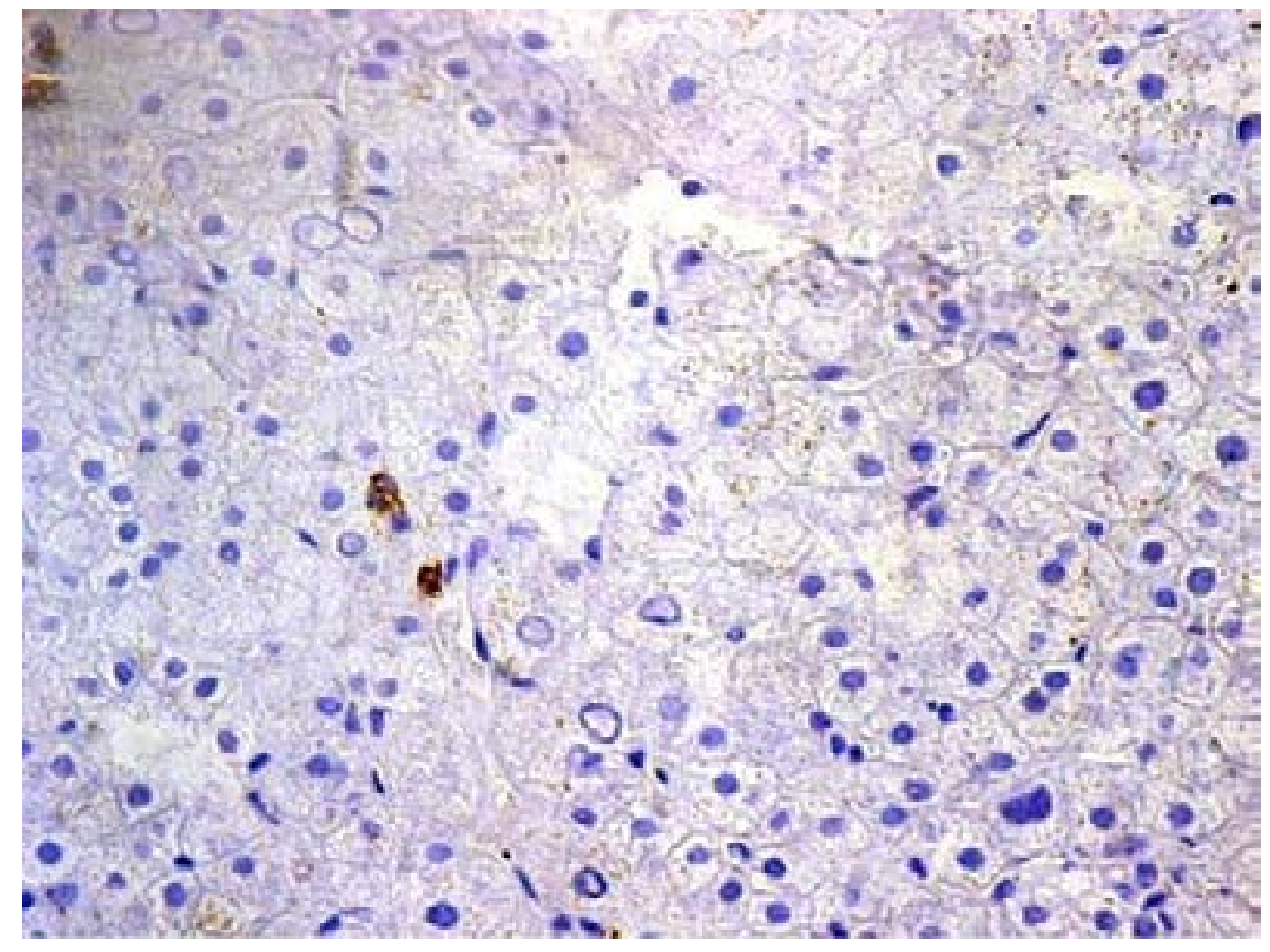

Figure (1): A case of normal control liver tissue showed scanty isolated

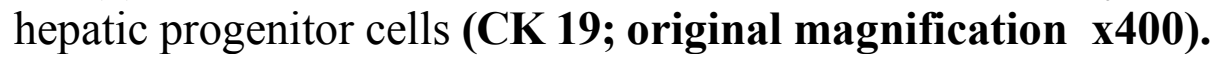

\section{Comparison between responders and non-respond-} ers

The mean number of HPCs expressed as DR was higher in non-responders (5.8) than responders (3.3). The difference was highly significant $(\mathrm{t}=-4.5, \mathrm{P}=0)$. Also, the mean number of IPCs was significantly higher in the non-responders (4.1) than responders (3.1) $(\mathrm{t}=-2.6, \mathrm{p}$
$=0.005)$. Conversely; no difference between responders and non-responders regarding the mean age of patients, gender, level of viremia, grade of disease activity, stage of fibrosis and status of steatosis (Table 1). By applying Wilcoxon Rank Sum test for multivariate analysis, we found that HPCs in the form of DR and IPCs were independent predictors of therapeutic response $(\mathrm{Z}=-4.5, \mathrm{P}=0$, $Z=-2.2, P=0.03$; respectively). 
Table (1): Comparison between responders and non-responders

\begin{tabular}{|c|c|c|c|c|}
\hline Factor & $\begin{array}{l}\text { Responders } \\
(\mathrm{N}=47)\end{array}$ & $\begin{array}{l}\text { Non-responders } \\
(\mathrm{N}=63)\end{array}$ & $t / \chi^{2}$ & $\mathbf{P}$ \\
\hline Mean age & 42.6 & 45.0 & $\mathrm{t}=-1.1$ & NS \\
\hline $\begin{array}{c}\text { Gender } \\
\text { Male } \\
\text { Female }\end{array}$ & $\begin{array}{l}42 \\
5\end{array}$ & $\begin{array}{l}54 \\
9\end{array}$ & $\chi^{2}=0.3$ & NS \\
\hline $\begin{array}{c}\text { Viremia } \\
\text { Low } \\
\text { High }\end{array}$ & $\begin{array}{l}34 \\
13\end{array}$ & $\begin{array}{l}38 \\
25\end{array}$ & $\chi^{2}=1.7$ & NS \\
\hline $\begin{array}{c}\text { Activity } \\
\text { A1 } \\
\text { A2 }+3\end{array}$ & $\begin{array}{l}27 \\
20\end{array}$ & $\begin{array}{l}34 \\
29\end{array}$ & $\chi^{2}=0.1$ & NS \\
\hline $\begin{array}{r}\text { Fibrosis } \\
\text { F1 + } 2 \\
\text { F3 }+4\end{array}$ & $\begin{array}{l}31 \\
16\end{array}$ & $\begin{array}{l}35 \\
28\end{array}$ & $\chi^{2}=1.2$ & NS \\
\hline $\begin{array}{l}\text { Steatosis } \\
\text { Absent } \\
\text { Present }\end{array}$ & $\begin{array}{l}29 \\
18 \\
\end{array}$ & $\begin{array}{l}33 \\
30 \\
\end{array}$ & $\chi^{2}=0.9$ & NS \\
\hline Mean DR & $3.3 \pm 1.6$ & $5.8 \pm 3.4$ & $t=-4.5$ & 0 \\
\hline Mean IPC & $3.1 \pm 1.7$ & $4.1 \pm 2.3$ & $t=-2.6$ & 0.005 \\
\hline
\end{tabular}

DR: Ductular reaction, IPC: Isolated progenitor cells, NS: No significant

Relationship between HPC expression and other variables in all cases

For DR, the mean number of positive cells was signifi- cantly higher in more active cases $(\mathrm{t}=-2.5, \mathrm{P}=0.007)$, in more advanced stages of fibrosis $(t=-6.7, P=0)$ and cases showing steatosis $(t=-4.5, P=0)$. 
IPCs were significantly more expressed in specimens with later stages of fibrosis $(t=-4.9, P=0)$ and those having steatosis $(\mathrm{t}=-4.2, \mathrm{P}=0)$. Both $\mathrm{DR}$ and IPCs were not related to the patient's age, gender or level of viremia (Ta- ble 2). Multivariate regression analysis showed that stage of fibrosis and steatosis were independent factors that significantly associated with the number of DR (F ratio $=$ 10.8, $\mathrm{P}=0)$ and IPCs $(\mathrm{F}$ ratio $=6.3, \mathrm{P}=0)$.

\section{Table (2): Relationship between HPC expression and other clinico- pathologic factors in 110 cases with chronic hepatitis $C$}

\begin{tabular}{|c|c|c|c|c|c|c|c|}
\hline \multirow{2}{*}{ Factor } & \multirow{2}{*}{$\begin{array}{l}\text { Number } \\
\text { of cases }\end{array}$} & \multicolumn{3}{|l|}{ DR } & \multicolumn{3}{|l|}{ IPCs } \\
\hline & & Mean & $\mathbf{t}$ & $\mathbf{p}$ & Mean & $\mathbf{t}$ & $\mathbf{p}$ \\
\hline $\begin{array}{c}\text { Age (years) } \\
\leq 40 \\
>40\end{array}$ & $\begin{array}{l}35 \\
74\end{array}$ & $\begin{array}{l}4.9 \\
4.7\end{array}$ & -0.4 & NS & $\begin{array}{l}3.5 \\
3.8 \\
\end{array}$ & -0.7 & NS \\
\hline $\begin{array}{c}\text { Gender } \\
\text { Male } \\
\text { Female } \\
\end{array}$ & $\begin{array}{l}96 \\
14 \\
\end{array}$ & $\begin{array}{l}3.4 \\
2.8 \\
\end{array}$ & -1.3 & NS & $\begin{array}{l}3.6 \\
4.2 \\
\end{array}$ & -0.9 & NS \\
\hline \multicolumn{8}{|l|}{ Viremia } \\
\hline $\begin{array}{l}\text { Low } \\
\text { High } \\
\end{array}$ & $\begin{array}{l}72 \\
38 \\
\end{array}$ & $\begin{array}{l}4.7 \\
4.7 \\
\end{array}$ & 0.1 & NS & \begin{tabular}{|l|}
3.6 \\
3.9 \\
\end{tabular} & -0.6 & NS \\
\hline $\begin{array}{l}\text { Activity } \\
\text { A1 } \\
\text { A2 +A 3 }\end{array}$ & $\begin{array}{l}61 \\
49 \\
49\end{array}$ & $\begin{array}{l}4.1 \\
5.5\end{array}$ & -2.5 & 0.007 & $\begin{array}{l}3.4 \\
4.1 \\
\end{array}$ & -1.6 & NS \\
\hline $\begin{array}{c}\text { Fibrosis } \\
\text { F1 +F } 2\end{array}$ & 66 & 3.4 & -6.7 & 0 & 3.0 & -4.9 & 0 \\
\hline $\mathrm{F} 3+\mathrm{F} 4$ & 44 & 6.7 & & & & & \\
\hline \multicolumn{8}{|l|}{ Steatosis } \\
\hline Absent & 62 & 3.7 & -4.5 & 0 & 3.0 & -4.2 & 0 \\
\hline Present & 48 & 6.1 & & & 4.6 & & \\
\hline
\end{tabular}

HPC: hepatic progression cells; DR: Ductular reaction, IPC: Isolated progenitor cells

NS: No significant 


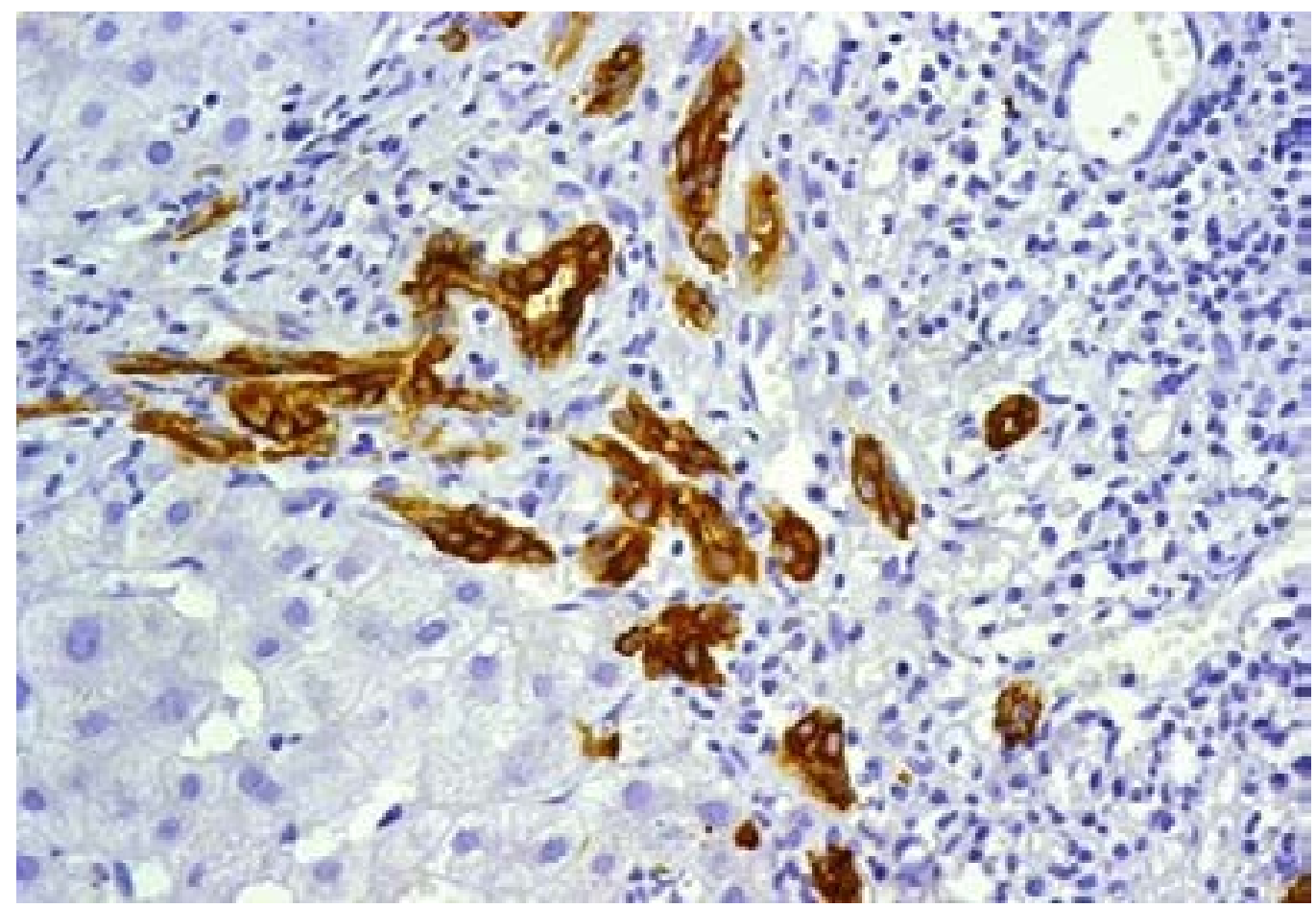

Figure (2): A case of chronic HCV showed a high number of hepatic progenitor cells expressed as ductular reaction and isolated

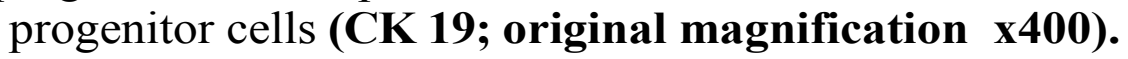

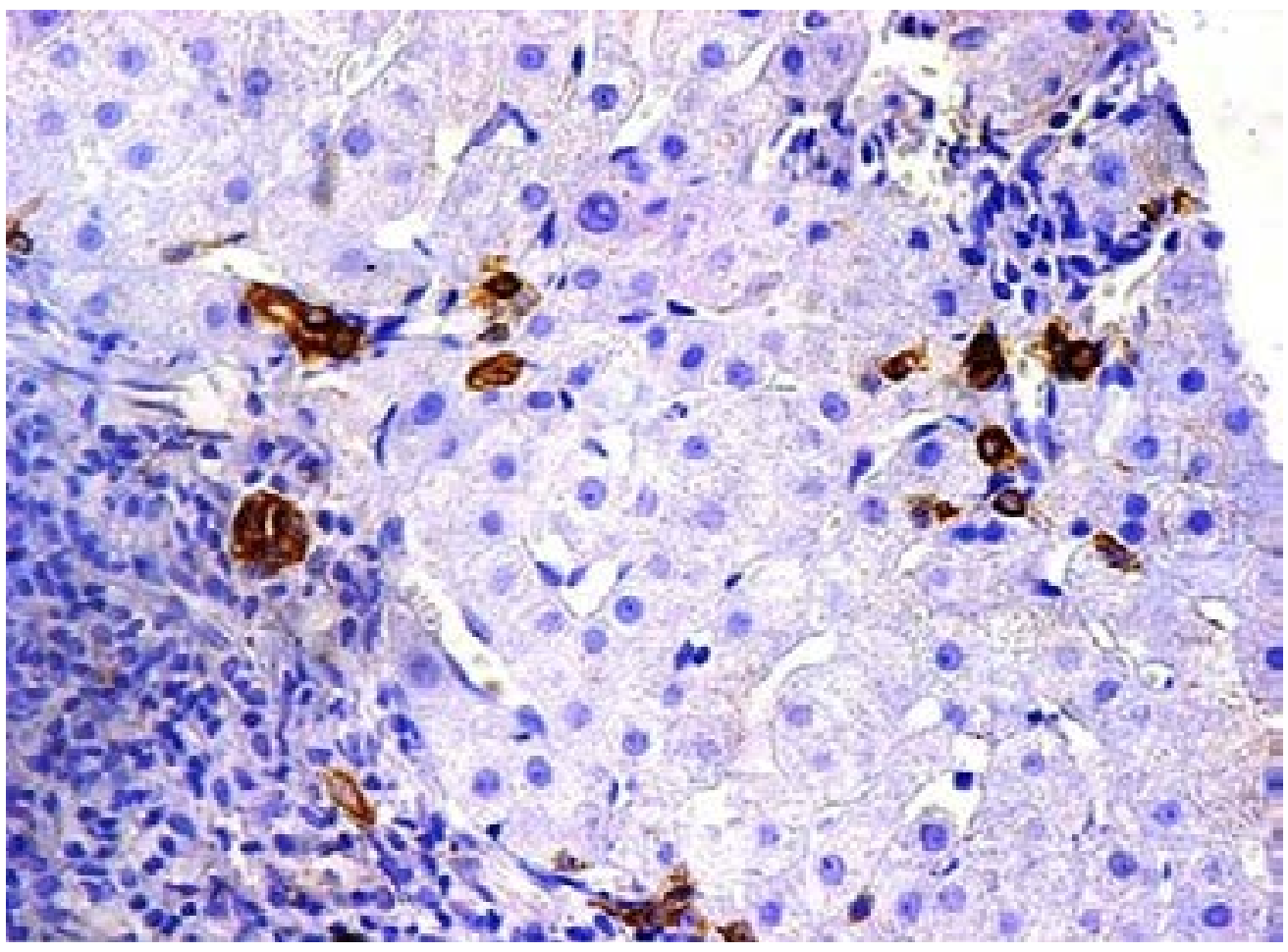

Figure (3): A case of chronic HCV showed a relatively low number of hepatic progenitor cells in the form of isolated progenitor cells

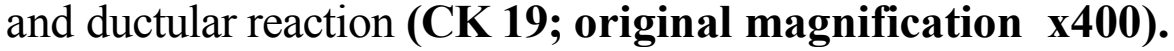


The means of DR cells and IPCs showed a highly signifi-

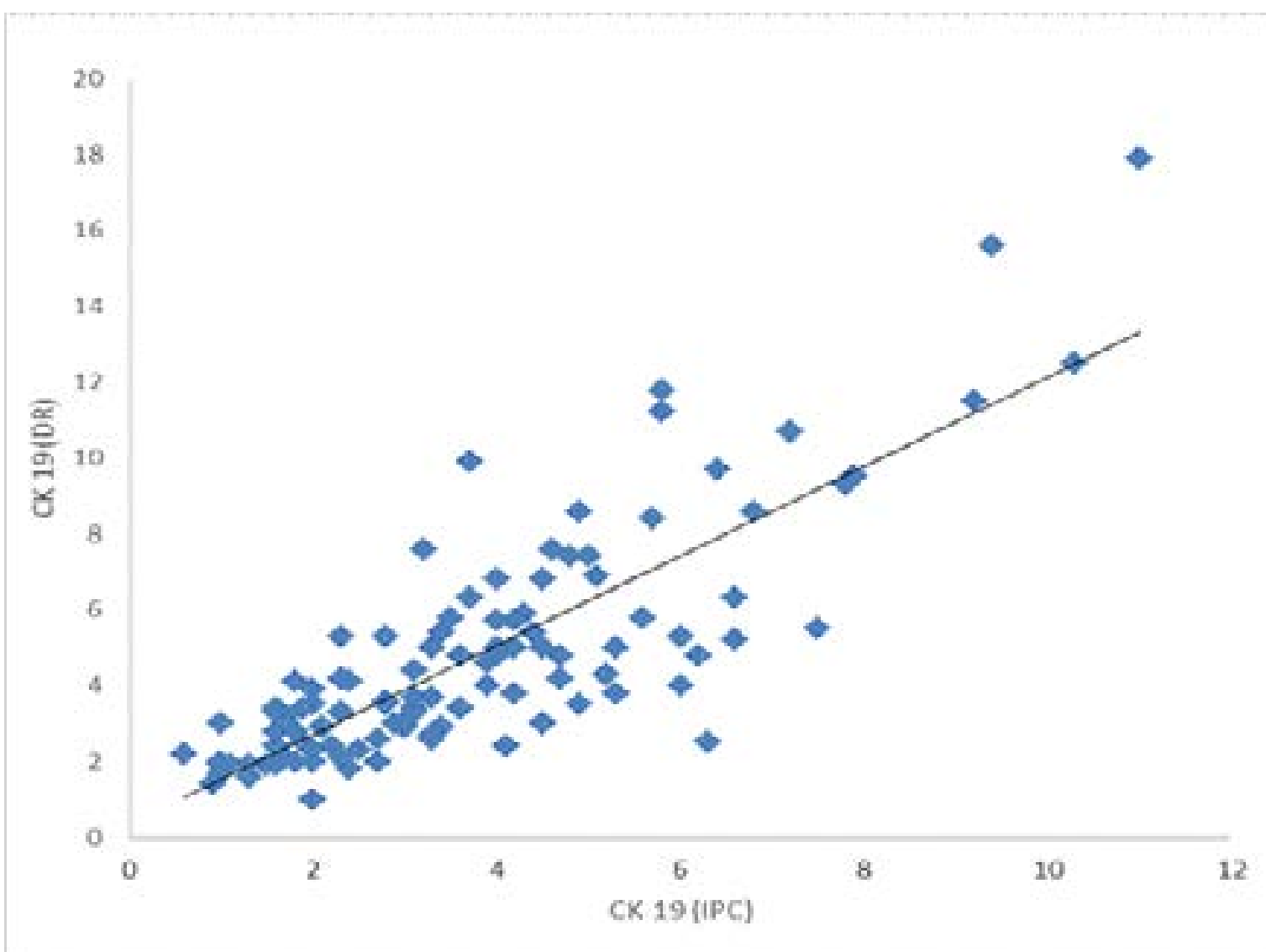

Figure (4): A highly significantly direct correlation between the number of ductular reaction (DR) and isolated progenitor cells $($ IPCs $)(r=0.8, P=0)$.

\section{Discussion}

Several studies investigated a series of viral and host factors to assess their potential value in prediction of response to interferon therapy in patients with chronic hepatitis $C^{26-30}$. Nevertheless, it has been noted that: First, most of these studies are controversial with no agreement on a reliable predictor of treatment response. Second, reported articles investigating the predictors of sustained virological response (SVR) in adult patients with $\mathrm{HCV}$ genotype 4 which is the most common type in Egypt, are very few ${ }^{10,31}$. Third, no previous reports analyzed the role of HPCs in predicting response of adult HCV patients to therapy, except that of Tsamandas et al. ${ }^{17}$ who studied 77 cases with various genotypes. These observations stimulated us to perform this work in an attempt to explore the role of HPCs in predicting SVR in 110 patients with chronic HCV genotype 4.
Sixty three of the 110 patients included in the study $(42.7 \%)$ yielded SVR. This is in line with Rizk et al. ${ }^{10}$ who obtained SVR in $45.5 \%$ of Egyptian patients with HCV, genotype 4. Higher levels of SVR (58\%) were reported in patients with genotype $3^{9}$ and lower levels (36\%) were observed in patients genotype 18 . These data support the conclusion of Jang and Chung ${ }^{32}$ that genotype 1 responds weakly to treatment, while genotype 3 responds better.

The current study confirmed previous reports that demonstrated HPCs in HCV-infected liver biopsies in the form of DR as well as IPCs ${ }^{18,33}$. More importantly, we found that responders (SVR) had a significantly lower number of HPCs (both DR and IPCs) than non-responders (Non-SVR). This result implies that assessment of HPCs in the pre-treatment liver biopsies of HCV pa- 
tients may be helpful in predicting the response to treatment. Similar data have been previously obtained by Tsamandas et al. ${ }^{17}$ who did not give explanation for such as important finding. HCV infection is known to induce cell cycle arrest and thus inhibit proliferation of normal mature hepatocytes. This inhibition promotes replication of HPCs as an alternative pathway ${ }^{34,35}$. Accordingly, we can speculate that in our patients who failed to achieve SVR, HCV protein which resisted response to therapy, was also able to mediate impairment of the cell cycle of mature liver cells and eventually contributes to HPC proliferation. It was interesting to compare our results with those of D'Ambrosio et al. ${ }^{33}$ and Noritake et al. ${ }^{18}$. Both studies estimated the immune expression of HPCs in pre-treatment and post-treatment liver biopsies of chronic HCV to evaluate the effect of interferon therapy on the expression of these cells. The authors found that the number of HPCs significantly decreased after SVR. Noritake et al. ${ }^{18}$ proposed that eradication of the virus could improve the HCV-related impairment of mature hepatocyte proliferation with consequent inhibition of HPC replication. Although the aim and design of the afore-mentioned two reports were different from ours, their conclusions are consistent with our findings.

Unexpectedly, there was no significant difference between responders and non-responders regarding the stage of fibrosis. This finding which agrees with previous studies ${ }^{8}$ $10,12,15$ indicates that cases with early stages of fibrosis may not respond to therapy and cases with late stages may respond. This is supported by the report of D'Ambrosio et al. $^{33}$ who studied the benefit of SVR in HCV patients with cirrhosis by evaluating pre- and post-treatment liver biopsies. The authors found that $61 \%$ of patients yielded a decrease of at least one METAVIR stage point in post-treatment biopsies. Another important observation in the present study was that the number of HPCs was significantly higher in later stages of fibrosis. This confirms several previous studies $90,10,17,18$ and indicates that HPCs participate either directly or indirectly through cross talk with stellate cells in the process of hepatic fibrogenesis. We investigated the relationship between stellate cells and HPCs in chronic HCV in a previous report ${ }^{36}$.

Steatosis is one of the hallmarks in the liver biopsies of chronic $\mathrm{HCV}^{37}$. In the current work, we observed that steatosis had no impact on response to therapy to $\mathrm{HCV}$ infection. This is in line with previous studies, ${ }^{9,33,38}$ On the other hand, we noted that the number of HPCs (both DR and IPCs) was significantly higher in biopsies having steatosis. This is in agreement with Clouston et al. ${ }^{39}$ who reported that steatosis induces proliferative blockade in $\mathrm{HCV}$-infected hepatocytes resulting into promotion of HPC replication.

The pre-treatment viral load has been assumed to be a useful predictor of response to treatment in chronic HCV9 . However, we and others ${ }^{8,10}$ could not support such an assumption. Gunal et al. ${ }^{11}$ suggested that this was due to small number of their cases and they were followed up by different PCR techniques. Our own view is that the response to HCV treatment may be related to the virulence power of the virus rather than its quantitative value in blood.

In the present study, it was interesting to note that DR and IPCs are always present together in all 110 liver biopsies. Furthermore, the number of both types of HPCs showed a highly significant direct correlation $(\mathrm{r}=0.8, \mathrm{P}$ $=0)$. This result was also reported by Clouston et al..$^{39}$ and El-Araby et al. ${ }^{12}$ who claimed that IPCs may represent the earlier stage of HPCs which is followed by DR formation.

Finally, our study may have some limitations. First, since it was retrospective, the cases were selective rather than consecutive according to the inclusion and exclusion criteria. So, selection bias couldn't be excluded. Second, the number of specimens was relatively small. However, it adequately represents the sample size required to produce specific statistical power. Third, the use of a single marker for HPCs may be considered a limitation. Nevertheless, $\mathrm{CK}^{19}$ was considered as the most sensitive marker for immunohistochemical identification of HPCs ${ }^{17,23}$. In spite of these limitations, the current study has the power of having all cases from one center with the same treatment protocols.

\section{Conclusion}

The present study is the first to explore the role of HPCs in predicting response to IFN therapy in adult chronic $\mathrm{HCV}$ patients with genotype 4 . The highly significant dif- 
ference between responders and non-responders regarding the number of HPC expression indicates that it can be used as an independent predictor to response to therapy in patients with chronic HCV, genotype 4. Undoubtedly, further studies on larger number of cases are mandatory before recommending immuno histochemical estimation of HPCs to predict response to HCV treatment.

\section{Competing interests}

The authors declare that they have no competing interests.

\section{References}

1. Bruggmann P, Berg T, Ovrehus AL, Moreno C, Branda Mello C E, Roudot-Thoraval, F.et al. Historical epidemiology of hepatitis $C$ virus (HCV) in selected countries. $J$ Viral Hepat. 2014; 21 Suppl 1: 5-33.

2. Centers for Disease $C$ and Prevention. Progress toward prevention and control of hepatitis $C$ virus infection--Egypt, 2001-2012. MMWR Morbidity and Mortality Weekly Report. 2012; 61: 545-549.

3. Feeney ER and Chung RT. Antiviral treatment of hepatitis C. BMJ. 2014; 348: g3308.

4. European Association for the Study of the L. EASL recommendations on treatment of hepatitis C 2014. J. Hepatol. 2014; 61(2): 373-395.

5. Asthana M, Sahu SK, Kumar A, Mohanty S, Chakrabarti S, Das, P. et al. Role of Interleukin 28B polymorphisms in response to Interferon based therapy for hepatitis $C$ virus clearance. Curr Drug Metab. 2018.

6. Ragab HM, El Maksoud NA, Amin MA, Halim MH, Abdulla NA, Kamel A. et al. IL-21 as a Predictor of Sustained Virologic Response in Patients with Chronic Hepatitis C Virus Infection. Appl Biochem and Biotech. 2017.

7. Fried MW. Side effects of therapy of hepatitis $C$ and their management. Hepatology. 2002 Nov; 36 (5 Suppl 1):S237-44

8. Sargolzaee Aval F, Behnaz N, Raoufy MR and Alavian SM. Predicting the outcomes of combination therapy in patients with chronic hepatitis $\mathrm{C}$ using artificial neural network. Hepat Mon. 2014 Jun 1; 14(6):e17028.

9. Marciano S, Borzi SM, Dirchwolf M, Ridruejo E, Mendizabal M, Bessone F. et al. Pre-treatment prediction of response to peginterferon plus ribavirin in chronic hepatitis C genotype 3. . World J Hepatol. 2015 Apr 8; 7(4):703-709.
10. Rizk HH, Hamdy NM, Al-Ansari NL, et al. Pretreatment Predictors of Response to PegIFN-RBV Therapy in Egyptian Patients with HCV Genotype 4. PLoS One. 2016 Apr 21; 11(4):e0153895.

11. Günal O, Barut H S and U E. The markers predicting response to Hepatitis $C$ virus treatment and evaluation of treatment responses. J Microbiol Infec Dis. 2012; 2: 100108.

12. El-Araby HA, Ehsan NA, Konsowa HA, Abd-Elaati BM and Sira AM. Hepatic progenitor cells in children with chronic hepatitis C: correlation with histopathology, viremia, and treatment response. Eur J Gastrentrol \& Hepatol. 2015 May; 27(5):561-569.

13. Younossi ZM, Birerdinc A, Estep M, Stepanova M, Afendy A and Baranova A. The impact of IL28B genotype on the gene expression profile of patients with chronic hepatitis $\mathrm{C}$ treated with pegylated interferon alpha and ribavirin. J Transl Med. 2012; 10: 25.

14. Youssef SS, Abbas EA, Abd el Aal AM, Omran MH, Barakat A and Seif SM. IL28B rs 12979860 predicts response to treatment in Egyptian hepatitis $\mathrm{C}$ virus genotype 4 patients and alpha fetoprotein increases its predictive strength. J Interferon Cytokine Res. 2014 Jul; 34(7):505-509.

15. Aref AM, Othman MS, Mamdouh S, Dabaa E, Hassanein $\mathrm{M}$ and saber MA. New biomarkers for response to treatment of HCV infected patients based on IP-10and IL 28B polymorphism analysis. Am J Biochem. 2016; 6: 122 - 129.

16. Farber E. Similarities in the sequence of early histological changes induced in the liver of the rat by ethionine, 2-acetylamino-fluorene, and 3'-methyl-4-dimethylaminoazobenzene. Cancer Res. 1956; 16(2): 142-148.

17. Tsamandas AC, Syrokosta I, Thomopoulos K, Zolota V, Dimitropoulou D, Liava A. et al. Potential role of hepatic progenitor cells expression in cases of chronic hepatitis $\mathrm{C}$ and their relation to response to therapy: a clinicopathologic study. Liver Int. 2006 Sep; 26(7):817-826.

18. Noritake H, Kobayashi Y, Ooba Y, Matsunaga E, Ohta K, Shimoyama S. et al. Successful Interferon Therapy Reverses Enhanced Hepatic Progenitor Cell Activation in Patients with Chronic Hepatitis C. J Interferon \& Cytokine Res. 2015; 35(12): 956-962.

19. Derbala M, Amer A, Bener A, Lopez AC, Omar M and El Ghannam M. Pegylated interferon-alpha 2b-ribavirin combination in Egyptian patients with genotype 4 chronic hepatitis. J Viral Hepat. 2005; 12(4): 380-385. 
20. El Naghi S, Abdel-Ghaffar TY, El-Karaksy H, Abdel-Aty E F, El-Raziky MS,

Allam AA. et al. Safety and efficacy of Hansenula-derived PEGylated-interferon alpha-2a and ribavirin combination in chronic hepatitis C Egyptian children. World J Gastroenterol. 2014; 20(16): 4681-4691.

21. Intraobserver and interobserver variations in liver biopsy interpretation in patients with chronic hepatitis C. The French METAVIR Cooperative Study Group. Hepatology. 1994; 20: 15-20.

22. Gadd VL, Melino M, Roy S, Horsfall L, O'Rourke P, Williams MR. et al. Portal, but not lobular, macrophages express matrix metalloproteinase-9: association with theductular reaction and fibrosis in chronic hepatitis C. Liver Int. 2013; 33(4): 569-79.

23. Tan J, Hytiroglou P, Wieczorek R, Park YN, Thung $\mathrm{SN}$. Arias B. et al. Immunohistochemical evidence for hepatic progenitor cells in liver diseases. Liver. 2002; 22(5): 365-373.

24. Hsu SM, Raine L and Fanger H. Use of avidin-biotin-peroxidase complex (ABC) in immunoperoxidase techniques: a comparison between $\mathrm{ABC}$ and unlabeled antibody (PAP) procedures. 1981; 29(4): 577-580.

25. Roskams TA, Theise ND, Balabaud C, Bhagat G, Bhathal PS, Bioulac-Sage P. et al. Nomenclature of the finer branches of the biliary tree: canals, ductules, and ductular reactions in human livers. Hepatology. 2004; 39(6): 1739-1745.

26. Hayes $\mathrm{CN}$, Imamura $\mathrm{M}$, Aikata $\mathrm{H}$ and Chayama $\mathrm{K}$. Genetics of IL28B and HCV--response to infection and treatment. Nat Rev Gastroenterol \& Hepatolo. 2012; 9(7): 406-417.

27. Al Ashgar H, Helmy A, Khan MQ, Al Kahtani K, Al Quaiz M, Rezeig M.et al. Predictors of sustained virological response to a 48-week course of pegylated interferon alfa-2a and ribavirin in patients infected with hepatitis $C$ virus genotype 4. Ann Saudi Med. 2009; 29(1): 4-14.

28. Antonucci G, Angeletti C, Vairo F, Longo MA and Girardi E. Age and prediction of sustained virological response to hepatitis $\mathrm{C}$ virus (HCV) infection treatment based on 28-day decrease in HCV RNA levels. $J$ infect dis. 2009; 200(9): 1484-1485.

29. Namazee N, Sali S, Asadi S, Shafiei M, Behnava B and Alavian SM. Real response to therapy in chronic hepatitis C virus patients: a study from iran. Hep Mon. 2012; 12(9): e6151.
30. Alavian SM, Tabatabaei SV, Keshvari M, Behnava B, Miri SM, Elizee P K. et al. Peginterferon alpha-2a and ribavirin treatment of patients with haemophilia and hepatitis $C$ virus infection: a single-centre study of 367 cases. Liver Int. 2010; 30(8): 1173-1180.

31. Khairy M, Fouad R, Mabrouk M, El-Akel W, Awad A B, Salama R. et al. The impact of interleukin $28 \mathrm{~b}$ gene polymorphism on the virological response to combined pegylated interferon and ribavirin therapy in chronic HCV genotype 4 infected egyptian patients using data mining analysis. Hep Mon. 2013; 13(7): e10509.

32. Jang JY and Chung RT. Chronic hepatitis C. Gut and Liver. 2011; 5(2): 117-132.

33. D'Ambrosio R, Aghemo A, Rumi MG, Ronchi G, Donato M F Paradis V. et al. A morphometric and immunohistochemical study to assess the benefit of a sustained virological response in hepatitis $C$ virus patients with cirrhosis. Hepatology. 2012; 56(2): 532-543.

34. Marshall A,Rushbrook S, Davies SE, Morris L S, Scott I S, Vowler S L. et al. Relation between hepatocyte G1 arrest, impaired hepatic regeneration, and fibrosis in chronic hepatitis C virus infection. Gastroenterology. 2005; 128(1): 33-42.

35. Roskams T, Yang SQ, Koteish A, Durnez A, DeVos $\mathrm{R}$, Huang $\mathrm{X}$. et al. Oxidative stress and oval cell accumulation in mice and humans with alcoholic and nonalcoholic fatty liver disease. Am J Pathol. 2003; 163(4): 1301-1311.

36. Helal T, Ehsan NA, Radwan NA and Abdelsameea E. Relationship between hepatic progenitor cells and stellate cells in chronic hepatitis C genotype 4. APMIS. 2018; 126(1): 14-20.

37. Leandro G, Mangia A, Hui J, Fabris P, Rubbia-Brandt L, Colloredo G. et al. Relationship between steatosis, inflammation, and fibrosis in chronic hepatitis C: a meta-analysis of individual patient data. Gastroenterology. 2006; 130(6): 1636-1642.

38. Mishra L, Banker'T, Murray J, Byers S, Thenappan A, He AR. et al. Liver stem cells and hepatocellular carcinoma. Hepatology. 2009; 49(1): 318-329.

39. Clouston AD, Powell EE, Walsh MJ, Richardson MM, Demetris AJ and Jonsson JR. Fibrosis correlates with a ductular reaction in hepatitis C: roles of impaired replication, progenitor cells and steatosis. Hepatology. 2005; 41(4): 809-818. 